\title{
Pendampingan Tenaga Pendidik dalam Meningkatkan Kreativitas Mengadaptasi Penggunaan Teknologi Pendidikan Jarak Jauh (PJJ) Dimasa Pandemi Covid 19
}

\author{
Khavisa Pranata, Arum Fatayan* \\ Universitas Muhammadiyah Prof. Dr. Hamka, Jakarta, Indonesia, \\ *Coresponding Author: arum_fatayan@gmail.ac.id \\ Dikirim: 21-01-2022; Direvisi: 23-01-2022; Diterima: 24-01-2022
}

\begin{abstract}
Abstrak: Pengabdian pendampingan tenaga pendidik dalam meningkatkan kreativitas mengadaptasi teknologi pendidikan jarak jauh (PJJ) dimasa pandemik covid 19 merupakan salah satu bentuk program kemitraan masyarakat yang dilakukan oleh dosen dan mahasiswa secara interdisipliner, instutisional, dan kemitraan sebagai salah satu bentuk kegiatan catur dharma perguruan tinggi Muhammadiyah. Tujuan Pengabdian ini adalah untuk meningkatkan kreatifitas Guru dan peserta didik yang belum bisa beradaptasi dalam penggunaan teknologi Pendidikan Jarak Jauh (PJJ). Metode yang digunakan dalam kegiatan pendampingan tenaga pendidik dalam meningkatkan kreativitas mengadaptasi teknologi pendidikan jarak jauh (PJJ) dimasa pandemik covid 19 ialah dengan metode pendampingan dan praktik, serta kegiatan dilaksanakan selama satu bulan. Adapun hasil dari kegiatan pendampingan tenaga pendidik dalam meningkatkan kreativitas mengadaptasi teknologi pendidikan jarak jauh (PJJ) dimasa pandemik covid 19 adalah adanya pemahaman baru bagi para guru didalam menyesuaikan pengajaran dimasa pandemik ini melalui platfrom pembelajaran daring dan juga pemahaman bagi siswa dan orang tua siswa dalam mengadaptasi teknologi.
\end{abstract}

Kata Kunci: Pembelajaran Jarak Jauh; Teknologi Pembelajaran; Covid 19

\begin{abstract}
The service of mentoring educators in increasing creativity in adapting distance education technology during the Covid 19 pandemic is a form of community partnership program carried out by lecturers and students in an interdisciplinary, institutional, and partnership manner as a form of Muhammadiyah tertiary dharma chess activities, The purpose of this Service is to increase the creativity of teachers and students who have not been able to adapt to the use of technology in Distance Education. The method used in mentoring activities for educators in increasing creativity in adapting distance education technology during the Covid 19 pandemic is the mentoring method and practice, the activity is carried out for one month. The results of the activities of mentoring educators in increasing creativity in adapting distance education technologi during the Covid 19 pandemic is that there is a new understanding for teachers in adjusting teaching during this pandemic through online learning platforms and also understanding for students and parents of students in adapting. technology.
\end{abstract}

Keywords: Distance Learning, Learning Tekhnology, Covid 19

\section{PENDAHULUAN}

Penyakit virus corona (COVID-19) adalah penyakit menular yang disebabkan oleh infeksi virus corona yang baru-baru ini ditemukan. Sebagian besar orang yang tertular COVID-19 akan mengalami gejala ringan hingga sedang. Virus yang menyebabkan COVID-19 terutama ditransmisikan melalui droplet (percikan air liur) yang dihasilkan saat orang terinfeksi batuk, bersin, atau menghembuskan nafas. Hal 
lain yang juga memengaruhi transmisi penyakit ini di masyarakat adalah bahwa seseorang yang positif terinfeksi dan tidak bergejala tetap dapat menularkan ke orang lain.

Sejak kemunculan kasus pertama positif Covid-19 di Indonesia tanggal 2 Maret 2020, jumlah kasus terkonfirmasi positif dan meninggal masih terus meningkat. Pandemi Covid-19 berdampak sistemik dan mengganggu hampir seluruh aspek kehidupan manusia termasuk di bidang pendidikan tinggi. Secara global, United Nation Educational, Scientific and Cultural Organization (UNESCO) melaporkan pada tanggal 20 April 2020 sudah 191 negara menutup satuan pendidikan dengan 1,575,270,054 peserta didik terdampak. Di Indonesia Pandemi Covid-19 berdampak pada 646.192 satuan pendidikan, 68.801.708 Peserta Didik, dan 4.183.591 Pendidik mulai dari jenjang Pendidikan Anak Usia Dini sampai Pendidikan Tinggi, Pendidikan Khusus, Pendidikan Vokasi, Pendidikan Masyarakat, Kursus dan Pendidikan Keagamaan (Kemdikbud, 2021).

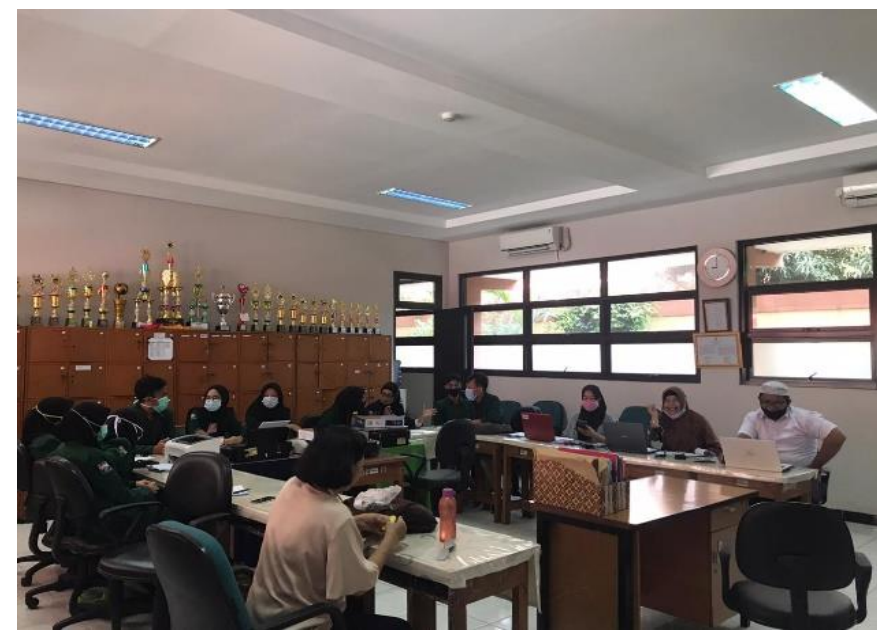

Gambar 1. diskusi bersama guru

Dalam menanggulangi dampak Covid-19, Pemerintah Indonesia mengambil kebijakan Pembatasan Sosial Berskala Besar (PSBB) dan menetapkan bencana nonalam penyebaran Covid-19 sebagai bencana nasional. Kebijakan ini berdampak langsung terhadap kegiatan yang bersifat komunal atau menghimpun orang banyak dalam suatu tempat, Sekolah merupakan institusi yang diliburkan dan siswa melakukan proses pembelajaran dari rumah (Harahap et al., 2020; Syarifuddin, Basri et al., 2021).

Sekolah Dasar Negeri Susukan 08 Pagi ini terletak di Jl. H. Baping, RT.10/RW.06, Susukan, Kec. Ciracas, Kota Jakarta Timur, Daerah Khusus Ibukota Jakarta. Dari hasil wawancara dengan Kepala sekolah dan guru SDN Susukan 08 pagi, ada beberapa kendala dalam proses KBM secara daring/Pendidikan jarak jauh diantaranya, kurangnya alat komunikasi yang dimiliki oleh wali murit pada setiap siswa, kurangnya akses yang dapat dilakukan guru terhadap perkembangan karena tidak adannya kegiatan luring, beberapa siswa yang kurang mengetahui informasi tugas, Siswa tidak punya HP, kalaupun ada keluhan guru terhadap pengajaran masih perihal alat komunikasi siswa yang belum memadai menggunakan berbagai macam platform lain selain WhatsApp dan bertemu wali murid, Masih banyak murid yang telat mengumpulkan tugas terkendala alat komunikasi, Guru mengeluhkan terhadap perkembangan anak yang tidak bisa dipantau secara langsung, sehingga guru 
menggahawatirkan perkembangan peserta didik yang menurun (Magdalena et al., 2020).

Secara besar prioritas permasalahan mitra yaitu:

1) Kapasitas mengajar guru di sekolah dalam pembelajaran literasi dan numerasi. Adaptasi Proses Pembelajaran Baru Selama COVID-19 masih kurang maksimal (Wuladari, et.al.,2020; Naila \& Khasna, 2021).

2) Penggunaan aplikasi dan modul adaptasi pembelajaran selama pandemi Covid-19 pada pengajar, peserta didik, dan wali murid belum familiar/ belum terbiasa (Suhendri et al., 2021; Surahman et al., 2020; Syarifuddin, Nugroho et al., 2021).

3) Guru belum maksimal mengadaptasi penggunaan teknologi secara efektif dalam kegiatan belajar dari rumah. Kegiatan yang dilakukan dapat membantu pembuatan perangkat pembelajaran yang berbasis teknologi untuk keperluan kegiatan belajar-mengajar (Sari, 2021; Chusna et al, 2020)

\section{METODE PELAKSANAAN KEGIATAN}

Metode yang digunakan dalam kegiatan pendampingan tenaga pendidik dalam meningkatkan kreativitas mengadaptasi teknologi pendidikan jarak jauh (PJJ) dimasa pandemik covid 19 ialah dengan metode pendampingan dan praktik, adapun kegiatannya adalah sebagai berikut:

1) Tahap Persiapan

a. Kordinasi antara Ketua kelompok dan anggota dosen serta anggota mahasiswa. Yang dilakukan secara melalui aplikasi zoom Cloud Meeting.

b. Perizinan kesekolah, meminta izin kepada pihak sekolah tempat bermitra yaitu di SDN susukan 08 Pagi yang dilakukan secara luring

c. Kordinasi kegiatan, Rapat dengan kepala sekolah mengenai pembagian tugas

2) Tahap Pelaksanaan

a. Membantu guru dalam adaptasi teknologi saat melaksanakan Pendidikan Jarak Jauh (PJJ)

b. Membantu Sekolah Dasar dalam peningkatan kapasitas mengajar, menjadi guru kunjung atau guru bantu di sekolah dalam pembelajaran literasi dan numerasi

c. Memperkenalkan penggunaan aplikasi dan modul adaptasi pembelajaran selama pandemi Covid-19 pada pengajar, peserta didik, dan wali murid.

d. Membantu pembuatan perangkat pembelajaran yang berbasis teknologi untuk keperluan kegiatan belajar-mengajar.

e. Melaksanakan dokumentasi selama kegiatan

3) Proses Penutupan

a. Melaksanakan evaluasi selama 1 bulan kegiatan

b. Membuat laporan kegiatan pengabdian pada masyarakat

\section{IMPLEMENTASI KEGIATAN DAN PEMBAHASAN}

Hasil dari kegiatan pendampingan tenaga pendidik dalam meningkatkan kreativitas mengadaptasi teknologi pendidikan jarak jauh (PJJ) dimasa pandemik covid 19 adalah adanya pemahaman baru bagi para guru didalam menyesuaikan pengajaran dimasa pandemik ini melalui platfrom pembelajaran daring dan juga

@2022 Bima Abdi (https://jurnal.bimaberilmu.com/index.php/ba-jpm) 
pemahaman bagi siswa dan orang tua siswa dalam mengadaptasi teknologi (Pohan, 2020). Adapun kegiatannya terlaksana adalah sebagai berikut:

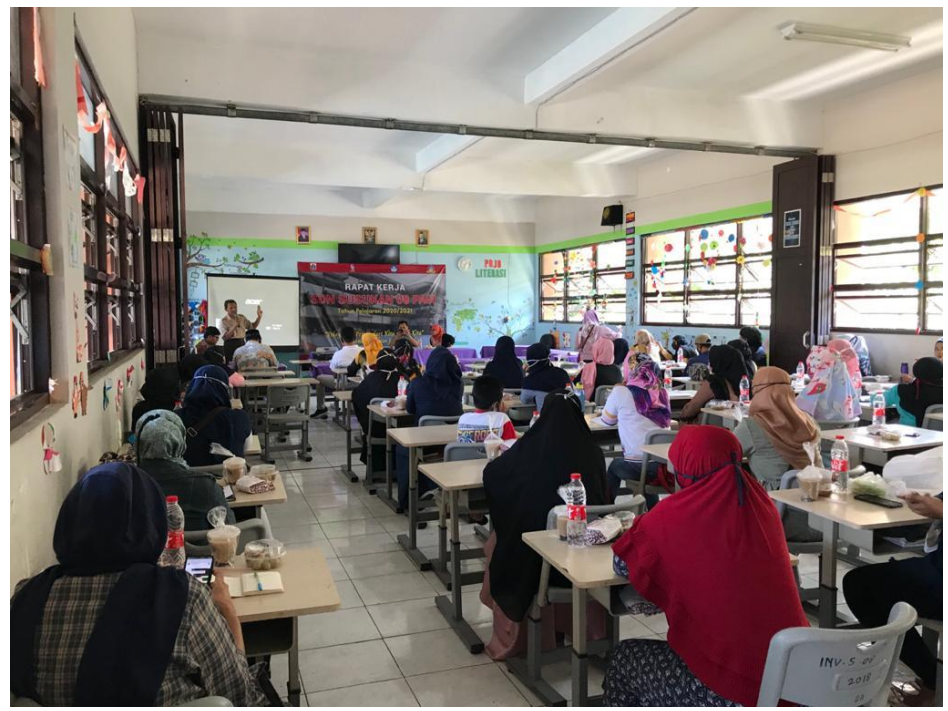

Gambar 2. kegiatn Pengabdian Masyarakat

Tabel 1. Jadwal Kegiatan Terlaksana

\begin{tabular}{|c|c|c|c|c|c|}
\hline No. & Jadwal kegiatan & Laporan & $\begin{array}{l}\text { Status } \\
\text { Lokasi }\end{array}$ & $\begin{array}{l}\text { Ruang } \\
\text { Publik } \\
\end{array}$ & Tanggal \\
\hline 1. & $\begin{array}{l}\text { Perizinan ke } \\
\text { sekolah }\end{array}$ & $\begin{array}{l}\text { Meminta izin } \\
\text { kepada pihak } \\
\text { sekolah SDN } \\
\text { Susukan } 08 \\
\text { Pagi }\end{array}$ & Luring & Sekolah & $\begin{array}{l}26 \text { Oktober } \\
2020\end{array}$ \\
\hline 3. & $\begin{array}{l}\text { Rapat dengan } \\
\text { Wakil Sekolah } \\
\text { mengenai } \\
\text { pembagian tugas }\end{array}$ & $\begin{array}{l}\text { Tidak ada } \\
\text { kendala }\end{array}$ & Luring & Sekolah & $\begin{array}{l}27 \text { Oktober } \\
2020\end{array}$ \\
\hline 4. & $\begin{array}{l}\text { Menata } \\
\text { perpustakaan } \\
\text { sekolah }\end{array}$ & $\begin{array}{l}\text { Tidak ada } \\
\text { kendala }\end{array}$ & Luring & Sekolah & $\begin{array}{l}\text { 02 November } \\
2020\end{array}$ \\
\hline 5. & $\begin{array}{l}\text { Membantu } \\
\text { membuat data } \\
\text { peralatan dan } \\
\text { perlengkapan } \\
\text { sekolah }\end{array}$ & $\begin{array}{l}\text { Tidak ada } \\
\text { kendala }\end{array}$ & Daring & $\begin{array}{l}\text { WhatsApp } \\
\text { Group }\end{array}$ & $\begin{array}{l}\text { 03 November } \\
2020\end{array}$ \\
\hline 6. & $\begin{array}{l}\text { Memberikan } \\
\text { materi HOTS di } \\
\text { SD }\end{array}$ & $\begin{array}{l}\text { Tidak ada } \\
\text { kendala }\end{array}$ & Daring & Zoom & $\begin{array}{l}\text { 04 November } \\
2020\end{array}$ \\
\hline 7. & $\begin{array}{l}\text { Membantu guru } \\
\text { membuat soal } \\
\text { ulangan harian }\end{array}$ & $\begin{array}{l}\text { Tidak ada } \\
\text { kendala }\end{array}$ & Daring & Zoom & $\begin{array}{l}05 \text { November } \\
2020\end{array}$ \\
\hline 8. & $\begin{array}{l}\text { pembahasan RPP } \\
\text { Daring }\end{array}$ & $\begin{array}{l}\text { Tidak ada } \\
\text { kendala }\end{array}$ & Daring & $\begin{array}{l}\text { Google } \\
\text { Meet }\end{array}$ & $\begin{array}{l}\text { 06 November } \\
2020\end{array}$ \\
\hline
\end{tabular}




\begin{tabular}{|c|c|c|c|c|c|}
\hline 9. & $\begin{array}{l}\text { Membantu Guru } \\
\text { Memberikan } \\
\text { pembelajaran } \\
\text { tematik SD }\end{array}$ & $\begin{array}{l}\text { Tidak ada } \\
\text { kendala }\end{array}$ & Daring & $\begin{array}{l}\text { Google } \\
\text { Meet }\end{array}$ & $\begin{array}{l}\text { 09 November } \\
2020\end{array}$ \\
\hline 10. & $\begin{array}{l}\text { Menata dan } \\
\text { menghias } \\
\text { perpustakaan } \\
\text { sekolah }\end{array}$ & $\begin{array}{l}\text { Tidak ada } \\
\text { kendala }\end{array}$ & Luring & Sekolah & $\begin{array}{l}10 \text { November } \\
2020\end{array}$ \\
\hline 11. & $\begin{array}{l}\text { Membantu Guru } \\
\text { Memberikan } \\
\text { pembelajaran } \\
\text { tematik SD }\end{array}$ & $\begin{array}{l}\text { Tidak ada } \\
\text { kendala }\end{array}$ & Daring & $\begin{array}{l}\text { Google } \\
\text { meet }\end{array}$ & $\begin{array}{l}11 \text { November } \\
2020\end{array}$ \\
\hline 12. & $\begin{array}{l}\text { Membantu Guru } \\
\text { Memberikan } \\
\text { pembelajaran } \\
\text { tematik SD }\end{array}$ & $\begin{array}{l}\text { Tidak ada } \\
\text { kendala }\end{array}$ & Daring & Zoom & $\begin{array}{l}12 \text { November } \\
2020\end{array}$ \\
\hline 13. & $\begin{array}{l}\text { Membantu guru } \\
\text { membuat soal } \\
\text { berbasis HOTS }\end{array}$ & $\begin{array}{l}\text { Tidak ada } \\
\text { kendala }\end{array}$ & Daring & Zoom & $\begin{array}{l}13 \text { November } \\
2020\end{array}$ \\
\hline 14. & $\begin{array}{l}\text { Membantu guru } \\
\text { membuat soal } \\
\text { berbasis HOTS }\end{array}$ & $\begin{array}{l}\text { Tidak ada } \\
\text { kendala }\end{array}$ & Daring & Zoom & $\begin{array}{l}16 \text { November } \\
2020\end{array}$ \\
\hline 15. & $\begin{array}{l}\text { Membantu guru } \\
\text { menggunakan } \\
\text { platfrom GCR }\end{array}$ & $\begin{array}{l}\text { Tidak ada } \\
\text { kendala }\end{array}$ & Luring & $\begin{array}{l}\text { Sekolah/ } \\
\text { Google } \\
\text { ClassRoom }\end{array}$ & $\begin{array}{l}17 \text { November } \\
2020\end{array}$ \\
\hline 16. & $\begin{array}{l}\text { Membantu guru } \\
\text { menggunakan } \\
\text { platfrom GCR }\end{array}$ & $\begin{array}{l}\text { Tidak ada } \\
\text { kendala }\end{array}$ & Luring & $\begin{array}{l}\text { Sekolah/ } \\
\text { Google } \\
\text { ClassRoom }\end{array}$ & $\begin{array}{l}18 \text { November } \\
2020\end{array}$ \\
\hline 17. & $\begin{array}{l}\text { Hadir dan } \\
\text { bergabung dalam } \\
\text { pembelajaran } \\
\text { daring kelas } 2 \text { di } \\
\text { Google Meet }\end{array}$ & $\begin{array}{l}\text { Tidak ada } \\
\text { kendala }\end{array}$ & Luring & $\begin{array}{l}\text { Sekolah } \\
\text { dan } \\
\text { Google } \\
\text { Meet }\end{array}$ & $\begin{array}{l}19 \text { November } \\
2020\end{array}$ \\
\hline 18. & $\begin{array}{l}\text { Membantu } \\
\text { 69enyusun RPP } \\
\text { Daring }\end{array}$ & $\begin{array}{l}\text { Tidak ada } \\
\text { kendala }\end{array}$ & Luring & Sekolah & $\begin{array}{l}20 \text { November } \\
2020\end{array}$ \\
\hline 19. & $\begin{array}{l}\text { Membantu dan } \\
\text { 69enyusun RPP } \\
\text { berbasis HOTS }\end{array}$ & $\begin{array}{l}\text { Tidak ada } \\
\text { kendala }\end{array}$ & Daring & Zoom & $\begin{array}{l}23 \text { November } \\
2020\end{array}$ \\
\hline 20. & $\begin{array}{l}\text { Membantu dan } \\
\text { 69enyusun RPP } \\
\text { berbasis HOTS }\end{array}$ & $\begin{array}{l}\text { Tidak ada } \\
\text { kendala }\end{array}$ & Luring & Sekolah & $\begin{array}{l}24 \text { November } \\
2020\end{array}$ \\
\hline 21. & $\begin{array}{l}\text { Membantu dan } \\
\text { 69penyusun RPP } \\
\text { berbasis HOTS } \\
\end{array}$ & $\begin{array}{l}\text { Tidak ada } \\
\text { kendala }\end{array}$ & Luring & Sekolah & $\begin{array}{l}25 \text { November } \\
2020\end{array}$ \\
\hline 2. & Pepisahan & $\begin{array}{l}\text { Tidak ada } \\
\text { kendala }\end{array}$ & Luring & Sekolah & $\begin{array}{l}27 \text { November } \\
2020\end{array}$ \\
\hline
\end{tabular}


Menteri Pendidikan dan Kebudayaan (Mendikbud) menerbitkan Surat Edaran Nomor 4 Tahun 2020 tentang tentang Pelaksanaan Kebijakan Pendidikan dalam Masa Darurat Penyebaran Covid-19. Mendikbud menekankan bahwa pembelajaran dalam jaringan (daring)/jarak jauh dilaksanakan dalam rangka memberikan pengalaman belajar yang bermakna bagi siswa, tanpa harus merasa terbebani tuntutan menuntaskan seluruh capaian kurikulum untuk persyaratan kenaikan kelas maupun kelulusan peserta didik di setiap instansi pendidikan. Surat Edaran nomor 15 tahun 2020 tentang Pedoman Penyelenggaraan Belajar Dari Rumah Dalam Masa Darurat Penyebaran Corona Virus Disease (COVID-19) menuliskan tujuan pelaksanaan Belajar Dari Rumah yaitu untuk memastikan pemenuhan hak peserta didik untuk mendapatkan layanan pendidikan selama darurat COVID-19; Melindungi warga satuan pendidikan dari dampak buruk COVID-19; Mencegah penyebaran dan penularan COVID-19 di satuan pendidikan; dan Memastikan pemenuhan dukungan psikososial bagi para pendidik, peserta didik dan orang tua/wali. Jadi dapat disimpulkan dengan kondisi dan landasan hukum terkait pandemic covid-19 saat ini pembelajaran daring harus sangat dilakukan untuk mengurangi resiko penyebaran covid-19 dan pembelajaran pun dapat terus berlangsung.

Penyebaran virus corona ini pada awalnya sangat berdampak bagi dunia ekonomi yang mulai lesu, dan akhirnya kini berdampak juga dirasakan oleh dunia pendidikan. Kebijakan yang sudah diambil oleh banyak negara dan termasuk Indonesia juga dengan meliburkan seluruh aktivitas pendidikan, dan membuat pemerintah dan lembaga terkait harus menghadirkan alternatif untuk proses pendidikan bagi peserta didik maupun mahasiswa yang sekarang tidak bisa melaksanakan proses pembelajaran atau proses pendidikan pada suatu lembaga pendidikan (Dewi, 2020). Di Indonesia, pembelajaran jarak jauh atau daring ini dimulai pada tanggal 16 maret 2020, dimana anak mulai belajar dari rumahnya masing-masing tanpa perlu pergi ke sekolah. Berbicara mengenai pembelajaran jarak jauh atau daring maka pentingnya penguasaan ilmu teknologi bagi seorang guru agar pembelajaran jarak jauh tetap berjalan dengan efektif disaat pandemi seperti ini. Konsekuensi dari penutupan Lembaga Pendidikan secara fisik dan mengganti dengan belajar di/dari rumah sebagaimana kebijakan pemerintah adalah adanya perubahan sistem belajar mengajar. Pengelola sekolah, siswa, orangtua, dan tentu saja guru harus bermigrasi ke sistem pembelajaran digital atau online, yang lebih dikenal dengan istilah e-learning atau dikenal dengan istilah pembelajaran dalam jaringan atau "pembelajaran daring" di Indonesia, dimana guru harus memastikan siswa dapat memperoleh informasi/ilmu pengetahuan untuk diberikan kepada siswa (Aulia, 2020). Pada masa pandemi ini, TIK berperan penting dalam Pembelajaran Jarak Jauh secara daring. Oleh karena itu banyak guru yang mengintegrasikan IT dalam proses pembelajaran karena banyak manfaatnya terutama untuk menunjang KBM secara daring (Oktaviani, 2020). Negara Indonesia juga relatif tidak berbeda dengan negara lain. Meskipun menyadari bahwa ada disparitas terhadap akses teknologi pembelajaran dan beragamnya latar belakang orang tua, Kementerian Pendidikan dan Kebudayaan Republik Indonesia dengan tegas memberlakukan kebijakan pembelajaran daring (Wahyono \& Husamah, 2020).

\section{KESIMPULAN}

@2022 Bima Abdi (https://jurnal.bimaberilmu.com/index.php/ba-jpm) 
Kegiatan pendampingan tenaga pendidik dalam meningkatkan kreativitas mengadaptasi teknologi pendidikan jarak jauh (PJJ) dimasa pandemik COVID-19 merupakan salah satu bentuk pengabdian kepada masyarakat yang dilakukan oleh dosen dan mahasiswa secara interdisipliner, instutisional, dan kemitraan sebagai salah satu bentuk kegiatan tridharma perguruan tinggi. Dosen dan mahasiswa dapat berkesempatan besar untuk berkontribusi dalam pencegahan penularan dan penanganan dampak COVID-19 di masyarakat dan guna menambahkan pengalaman dan rasa tanggung jawab terhadap masyarakat. Dengan adanya pendampingan tenaga pendidik dalam meningkatkan kreativitas mengadaptasi teknologi pendidikan jarak jauh (PJJ) dimasa pandemik COVID-19 ini diharapkan dapat memberikan banyak manfaat bagi dosen, mahasiswa dan guru di SD Negeri Susukan 08 Pagi terutama dalam proses Pembelajaran Jarak Jauh (PJJ).

\section{UCAPAN TERIMA KASIH}

Terimakasih Kepada LPPM Universitas Muhammadiyah Prof..DR..HAMKA dan SD Negeri Susukan 08 Pagi dan pihak lainnya yang telah membantu.

\section{DAFTAR PUSTAKA}

Aulia, S. (2020, Juli). Pembelajaran Daring Pada Masa Pandemi. Retrieved from Suara.com: https://www.suara.com/yoursay/2020/07/20/175556/pembelajarandaring-pada-masa-pandemi

Dewi, W. F. (2020). Dampak COVID-19 terhadap Implementasi Pembelajaran Daring di Sekolah Dasar. Edukatif : Jurnal Ilmu Pendidikan.

Harahap, S., Wahdi, H., \& Harapan, U. P. (2020). KESIAPAN MENGHADAPI PERUBAHAN PADA GURU SEKOLAH. Jurnal Administrasi Dan Manajemen Pendidikan, 3(4), 359-369.

Kemdikbud. (2021). Dashboard Guru dan Tenaga Kependidikan (GTK). DASHBOARD GTK.

https://referensi.data.kemdikbud.go.id/dashboardgtk/home.php?id=10

Magdalena, I., Yuliani, T., Kurniawan, I., \& Arief, S. (2020). Kendala Pembelajaran Jarak Jauh Secara Daring Pada guru Sekolah Dasar di SD Al Fattaah. PENSA : Jurnal Pendidikan Dan Ilmu Sosial, 2, 298-306. https://ejournal.stitpn.ac.id/index.php/pensa/article/view/966/668

Medita Ayu Wuladari, Hana Sakura Putu Arga, Jajang Bayu Kelana, Deden Herdiana Altaftazani, S. R. (2020). Analisis Pembelajaran "Daring” Pada Guru Sekolah Dasar Di Era Covid-19. Jurnal Ilmiah P2M STKIP Siliwangi P2M STKIP Siliwangi, 7(2), 164-168.

Naila, I., \& Khasna, F. T. (2021). Pengaruh Pembelajaran Daring Terhadap Kemampuan Literasi Sains Calon Guru Sekolah Dasar: Sebuah Studi Pendahuluan. ... Dasar: Jurnal Kajian Pendidikan Dan Hasil ..., 7(1), 42-47.

Oktaviani, L., Mandasari, B., \& Maharani, R. A. (2020). Implementing Powtoon to Improve Students International Culture Understanding in English. 19-25. 
Pohan, S. S. (2020). Paradigma Pengajaran Jarak Jauh ( Pjj ) Bagi Guru. SEUNEUBOK LADA, 7(1), 164-178.

Puji Asmaul Chusna, \& Ana Dwi Muji Utami. (2020). Dampak Pandemi Covid-19 Terhadap Peran Orang Tua Dan Guru Dalam Meningkatkan Kualitas Pembelajaran Daring Anak Usia Sekolah Dasar. PREMIERE: Journal of Islamic Elementary Education, 2(1), 11-30. https://doi.org/10.51675/jp.v2i1.84

Sari, Q. I. P. (2021). Coaching Online Pembelajaran Jarak Jauh Bagi Guru Sekolah Dasar. Jurnal Pengabdian Magister Pendidikan IPA, 4(1). https://doi.org/10.29303/jpmpi.v4i1.595

Suhendri, Sabri, R., Arifin, Z., Rahman, M. A., Ainaya, T., \& Fahmi, A. (2021). PELATIHAN PEMBELAJARAN JARAK JAUH ( PJJ ) PADA MASA PANDEMI COVID - 19 BAGI GURU SEKOLAH DASAR ISLAM TERPADU ( SDIT ) DOD MEDAN Abstrak. Jurnal Pengabdian Kepada Masyarakat ..., 27(1), 1-5.

Surahman, E., Ulfa, S., Sulthoni, \& Sumaji. (2020). Pelatihan Perancangan Pembelajaran Berbasis Computational Thinking untuk Guru Sekolah Dasar. JURPIKAT (Jurnal Pengabdian Kepada Masyarakat), 1(2), 60-74. https://doi.org/10.37339/jurpikat.v1i2.277

Syarifuddin, S., Nugroho, P. B., Fadhli, M., Murtalib, M., Mutmainah, M., Muchlis, M., ... \& Hadi, A. M. (2021). Sosialisasi Aplikasi Pembelajaran Jarak Jauh dan Pengembangan Bahan Ajar bagi Dosen, Guru, dan Mahasiswa di Era Pandemi Covid-19. Bima Abdi: Jurnal Pengabdian Masyarakat, 1(1), 30-36.

Syarifuddin, S., Basri, H., Ilham, M., \& Fauziah, A. F. (2021). Efektifitas Pembelajaran Daring Mahasiswa Pendidikan Matematika ditengah Pandemi Covid-19. JagoMIPA: Jurnal Pendidikan Matematika dan IPA, 1(1), 1-8.

Wahyono, P., \& Husamah, H. (2020). Jurnal Pendidikan Profesi Guru, 51-65. 